NBER WORKING PAPER SERIES

\title{
THE INCIDENCE OF A FIRM-VARYING \\ PAYROLL TAX: THE CASE \\ OF UNEMPLOYMENT INSURANCE
}

\author{
Patricia M. Anderson \\ Bruce D. Meyer
}

Working Paper No. 5201

\author{
NATIONAL BUREAU OF ECONOMIC RESEARCH \\ 1050 Massachusetts Avenue \\ Cambridge, MA 02138 \\ August 1995
}

We would like to thank Joe Altonji, David Card, Jon Gruber and Carolyn Moehling for their comments. This project was begun with funding under Purchase Order No. M-4466-4-00-96-40 from the U.S. Department of Labor, Advisory Council on Unemployment Compensation. Opinions stated in this document do not necessarily represent the official position or policy of the U.S. Department of Labor, Advisory Council on Unemployment Compensation. Much of the work on this paper was carried out while Anderson was a visitor to the Economics Program in the Research School of Social Sciences at the Australian National University. This paper is part of NBER's research programs in Labor Studies and Public Economics. Any opinions expressed are those of the authors and not those of the National Bureau of Economic Research.

( 1995 by Patricia M. Anderson and Bruce D. Meyer. All rights reserved. Short sections of text, not to exceed two paragraphs, may be quoted without explicit permission provided that full credit, including $\odot$ o notice, is given to the source. 


\title{
THE INCIDENCE OF A FIRM-VARYING \\ PAYROLL TAX: THE CASE \\ OF UNEMPLOYMENT INSURANCE
}

\begin{abstract}
In this paper we theoretically and empirically examine the common, but previously unexamined, case of a firm-varying tax which is used to finance a fringe benefit. While we use data from the experience-rated unemployment insurance (UI) system, it is important to realize that differential treatment of firms (such as special considerations for small business) under mandated benefits laws leads to costs which vary across firms and are analogous to experiencerated taxes. We present a theoretical model which highlights the importance of considering this variation in taxes or costs both within and across markets. We examine annual changes in either firm average earnings and employment or individual worker earnings at the same firm. This method removes unmeasured firm and worker characteristics, and thus avoids the omitted variable bias that has plagued past work on incidence and compensating differentials. Our results suggest that most of the market level tax is borne by the worker. However, this does not imply that there are no employment effects of the tax. Rather, we find that individual firms can only pass on a small share of the within market differences in the tax they face, leading to substantial employment reallocation across firms.
\end{abstract}

Patricia M. Anderson

Department of Economics

Dartmouth College

6106 Rockefeller

Hanover, NH 03755-3514

and NBER
Bruce D. Meyer

Department of Economics Northwestern University

2003 Sheridan Road

Evanston, IL 60208

and NBER 


\section{Introduction}

The usual textbook example of the incidence of a payroll tax assumes that a uniform tax rate is paid by all firms in a given market. The same assumption is often made for the similar case of a mandated benefit, where the benefit cost is assumed to be the same for all firms. In fact, variation across firms in payroll tax rates or the costs of mandates is very common. For example, the Clinton health care reform proposal would have levied rates ranging from 3.5 to 7.8 on firms depending on their size and wage level. Similarly, employer mandates such as the Worker Adjustment and Retraining Notification Act (WARN), the Family Leave Act, and the Americans with Disabilities Act (ADA) only apply to large firms (over 100 employees for the WARN, over 14 for the ADA). Often, programs that use payroll taxes to finance benefits, such as Workers' Compensation (WC) and Unemployment Insurance (UI), are experience rated, leading to variation across firms in payroll tax rates. In this paper we extend the theory of tax incidence to include the case of a firm-varying payroll tax. We then implement this theory empirically using panel data from state UI systems. Since this large variation in UI tax rates is due to experience rating and since the tax finances a benefit, our theoretical model also allows for these features.

Analyzing the incidence of the UI payroll tax is useful not only for answering the broader question of the effects of payroll taxes and mandated benefits on wages and employment, but is also important in its own right for several reasons. First, to assess the policy effects of a UI program, we need to know who ultimately pays for its costs. Is it consumers through higher prices, workers through lower wages, or owners of capital through lower profits? Second, an important branch of the UI literature focuses on the incentives created by different UI tax systems. In particular, the role of imperfect experience rating in encouraging the use of layoffs has been emphasized. ' An underlying assumption of this work, however, is that the employer bears at least

\footnotetext{
'See Brechling (1977, 1981), Topel (1983, 1990), Card and Levine (1994), Anderson and Meyer (1994), for examples.
} 
some burden of the UI payroll tax, since experience rating induced increases in tax rates will not provide an incentive to reduce layoffs if such increases can be shifted on to workers or consumers.

While there appears to be no past empirical work on the incidence of the UI payroll tax, there is related work in such areas as the effects of payroll taxes and benefits (mandated or not) on wages and employment. Previous studies of the incidence of payroll taxes have tended to use aggregate data, though, and often do not estimate a market equilibrium, focusing instead on one side of the market only. This literature is summarized in Hamermesh (1993) who concludes that "it is impossible to draw any firm conclusions about the incidence of the payroll tax from these studies..." because of estimation problems and a wide range of estimates.

The literature on the effects of fringe benefits and working conditions on wages has found mixed evidence, except that in most cases a compensating differential for the risk of injury and death is found. ${ }^{2}$ One of the key problems discussed in this literature is that of unmeasured worker characteristics and the difficulty of measuring worker productivity. This literature also emphasizes the importance of unmeasured firm characteristics that may be correlated with wages, fringe benefits and working conditions. The differences in wages across workers due to these omitted individual or firm factors will severely bias the estimation of compensating differentials. ${ }^{3}$ In this paper, we are able to address these problems by making use of the panel nature of our data set to difference out these individual and firm characteristics. That is, we examine the effects of tax changes on either changes in firm average earnings or changes in individual worker earnings at the same firm.

A third literature examines the effects of benefit mandates on worker earnings and employment. Recent studies have examined the effects of mandated workers' compensation and health benefits (Gruber and Krueger 1991, and Gruber 1994), and found that most of the costs of

\footnotetext{
${ }^{2}$ For summaries of the literature see Smith (1979), Brown (1980), Smith and Ehrenberg (1983), Triplett (1983), Rosen (1987), and Woodbury and Huang (1991).

${ }^{3}$ For statements of these problems see Brown (1980), Leibowitz (1983), Smith and Ehrenberg (1983), and Montgomery, Shaw and Benedict (1992).
} 
- these mandates are passed on to workers through lower wages. These studies, however, are not able to differentiate between firm-level variation in tax rates or costs and market-level variation, as we are able to do.

The UI literature has long recognized the importance of the firm-level variation in tax rates, though. For example, a thorough discussion of the incidence of the UI payroll tax can be found in Lester (1962), who argued that most of the incidence of the UI tax will fall on firms. Lester assumed that most firms operate in competitive industries and will not be able to shift most of the tax by lowering wages or raising prices. He also rests his argument on evidence from the 1950's that there are firms at both the minimum and maximum rates in most industries (generally defined at the 2-digit SIC level), and that most of the minimum rates are very low. Thus, most of this component of variation in taxes should not be shiftable if firms are price takers in the labor and product markets. He concluded that only the federal tax (which is currently .8 percent) is potentially shiftable. Since on average taxes are 2.1 percent of taxable wages, this would imply that only about forty percent of the tax might be shiftable. In past work, we have established that a wide range of tax rates within a state continues to exist within 2-digit industry groups (Anderson and Meyer, 1992). The difference between the 25 th and 75 th percentiles of the tax rate distribution averages about 1.5 percentage points. The 2 -digit industry classification is likely to be too broad a definition of competing firms in many cases, however. On the other hand, some of the industries (particularly manufacturing) have national output markets rather than state ones.

Hamermesh (1977) concludes that in the long run the incidence of the UI tax will fall about half on workers and half on consumers. He argues that the federal tax cannot be avoided by workers by changing jobs. Furthermore, the low level of excess profits in our economy prevents the UI tax from falling heavily on profits. Thus, the state part of the tax will likely result in long run increases in prices, though it may fall on firms in the short run.

To this point, then, empirical work on tax incidence has used only cross-market variation, while the work on within-market variation has remained theoretical. Using administrative data from eight states, this paper directly examines the relationship between a firm's UI tax rate and the 
- wages paid to its employees. In the next section, we present a theoretical model of the incidence of a firm-varying payroll tax, while Section III discusses the empirical implementation of the model. Section IV then presents the empirical results, while Section V concludes.

\section{The Theoretical Effects of the UI Payroll Tax on Wages and Employment}

In the text book example of the effects of a payroll tax, the demand curve shifts downward and to the left, reducing the equilibrium wage and employment. The magnitude of the effect on the wage and employment depends on the demand and supply elasticities of labor. This textbook version can easily be modified for the case where the tax finances a new benefit which the worker values. ${ }^{4}$ Because the worker values the new benefit, there will be a downward and rightward shift of the supply curve that will exaggerate the wage effect, but which may counteract and possibly even reverse the adverse employment effects of the tax. For experience-rated systems such as UI, though, it may be the case that the demand curve does not shift fully to reflect the tax. With experience rating, a current change in taxes paid tends to generate subsequent countervailing changes which dampen the present value of the change in taxes paid. ${ }^{5}$ We analyze in detail below how the value of UI benefits to the worker and the cost to the firm varies with $\tau$. Briefly, $\alpha$ depends on the layoff probability and the replacement rate, and $\beta$ depends on the expected permanence of a tax change. Taking these modifications into consideration, then, we can write the demand for labor as a function of the market wage $\mathrm{W}_{\mathrm{m}}$, the market tax $\tau_{\mathrm{m}}$, and $\beta_{\mathrm{m}}$, the true cost of the tax at the market level as a fraction of the tax (which may differ from one because of experience rating)

\footnotetext{
${ }^{4}$ See Burkhauser and Turner (1985), Summers (1989), and Gruber and Krueger (1991).

${ }^{5}$ We are grateful to Roger Gordon for this point.
} 
- $\quad D=f_{m}^{d}\left(W_{m}+\beta_{m} \tau_{m}\right)$

and the supply curve as a function of $\mathrm{W}_{\mathrm{m}}, \tau_{\mathrm{m}}$, and $\alpha_{\mathrm{m}}$, the workers' valuation of the benefit provided as a fraction of the tax

$S=f_{m}^{s}\left(W_{m}+\alpha_{m} \tau_{m}\right)$.

Then, total differentiation of the equilibrium condition $\mathrm{D}=\mathrm{S}$ gives the change in the wage rate in response to the tax,

$$
\frac{d W_{m}}{d \tau_{m}}=-\frac{\alpha_{m} \eta_{m}^{s}-\beta_{m} \eta_{m}^{d}}{\eta_{m}^{s}-\eta_{m}^{d}}
$$

where $\eta_{m}^{s}$ and $\eta_{m}^{d}$ are the market elasticity of labor supply and demand, respectively. Note that the usual case assumes $\beta_{\mathrm{m}}=1$ and $\alpha_{\mathrm{m}}=0$.

The change in employment in response to the tax is then given by

$$
\frac{d E_{m}}{d \tau_{m}}=\frac{\left(\beta_{m}-\alpha_{m}\right) \eta_{m}^{d} \eta_{m}^{s}}{\eta_{m}^{s}-\eta_{m}^{d}} \frac{E_{m}}{W_{m}}
$$

where $E_{m}$ is employment. This is the usual equation for the employment response to a tax except that it has been modified by the factor $\left(\beta_{\mathrm{m}}-\alpha_{\mathrm{m}}\right)$. Thus, as $\alpha_{\mathrm{m}}$ and $\beta_{\mathrm{m}}$ move toward each other, from 0 and 1 respectively, the employment effect goes from the standard case to that of no response to the tax. Note that this zero employment effect can occur with less than complete shifting of the wage, and that if $\alpha_{\mathrm{m}}>\beta_{\mathrm{m}}$, then the employment effect will actually be positive.

These equations, though, are derived for a payroll tax with a single rate for all firms. In order to analyze the effect of a firm-varying tax, we add a competitive market constraint which says that the wage plus the worker valuation of fringe benefits is equalized across firms:

$$
W_{m}+\alpha_{m} \tau_{m}=W_{f}+\alpha_{f} \tau_{f},
$$

where the $m$ subscript stands for market and the f subscript stands for firm. Completely differentiating as above, and setting $d \tau_{m}=0$ we obtain the effect of a change in the firm tax, holding the market tax constant, 
(3) $\frac{d W_{f}}{d \tau_{f}}=-\alpha_{f}$

The corresponding employment effect can then be calculated as,

$$
\frac{d E_{f}}{d \tau_{f}}=\left(\beta_{f}-\alpha_{f}\right) \frac{E_{f}}{W_{f}} \eta_{f}^{d}
$$

where $\eta_{f}^{d}$ is the firm's elasticity of labor demand. Similarly, we can set $d \tau_{f}=0$ to obtain the effect of a change in the market tax, holding the firm tax constant,

$$
\frac{d W_{f}}{d \tau_{m}}=\frac{\left(\beta_{m}-\alpha_{m}\right) \eta_{m}^{d}}{\eta_{m}^{s}-\eta_{m}^{d}}
$$

In this case the corresponding employment effect is

$$
\frac{d E_{f}}{d \tau_{m}}=\left[\frac{\left(\beta_{m}-\alpha_{m}\right) \eta_{m}^{d}}{\eta_{m}^{s}-\eta_{m}^{d}}\right] \frac{E_{f}}{W_{f}} \eta_{f}^{d}
$$

We should note that these equations are partial equilibrium results. In particular, they ignore likely shifts in the firm demand curve in response to a market tax. The expectation would be that such shifts in the firm demand curve in response to changes in the market tax would exaggerate the effects in (5) and (6) that work through the wage. The decline in output at other firm would likely decrease the market wage and shift out demand for the output of the firm in question. Equations (1) through (6) now give clear predictions about the effects of taxes, conditional on the $\alpha$ 's and $\beta$ 's, with the intuition behind the predictions being relatively straightforward. An increase in the tax at the market-level causes a competitive firm to face a new, lower wage rate. Holding constant the firm-level tax, then, we expect a negative wage effect and a positive employment effect of an increase in the market-level tax. Similarly, holding constant the market tax, a wage-taking firm will be unable to lower its wage in response to an increase in its own tax, and will respond with a reduction in employment. However, to the extent that the benefit is valued, the firm will be able to lower the money wage, so that if $\alpha_{\mathrm{f}} \geq \beta_{\mathrm{f}}$, there will be a negative wage effect, but a non-negative 
- employment effect, which will be zero for the case of $\alpha_{\mathrm{f}}=\beta_{\mathrm{r}}$. Holding constant the firm tax, there will be no effect of a change in the market tax if $\alpha_{m}=\beta_{m}$, but there will be a negative (positive) wage effect and positive (negative) employment effect as $\alpha_{\mathrm{m}}$ declines (rises) and $\beta_{\mathrm{m}}$ rises (declines). Table 1 provides a summary of these theoretical predictions for the sign and magnitude of the regression coefficients on firm- and market-level taxes in both the wage and employment equations.

Given the dependence of the predicted outcomes on the workers' valuation of the benefits they receive due to the tax and the firm's discounting of the tax, it is important to understand what determines these $\alpha$ 's and $\beta$ 's in our case. The simplest way to express the valuation of UI benefits by the workers is to write the supply of labor as a function of the utility level offered by a job rather than of the wage level. Ignoring subscripts, then, a general supply equation is written as $S=f^{s}(U(W, R, p))$, where $\mathrm{U}(\bullet, \bullet, \bullet)$ is utility as a function of the wage rate $W$, the $\mathrm{UI}$ replacement rate $\mathrm{R}$, and the layoff probability p. Again, totally differentiating the equilibrium condition yields the following analog to equation (1):

$$
\frac{d W}{d \tau}=-\frac{\left(\frac{\partial U}{\partial W}\right)^{-1}\left(\frac{\partial U}{\partial R} \frac{d R}{d \tau}+\frac{\partial U}{\partial p} \frac{d p}{d \tau}\right) \eta^{s}-\beta \eta^{d}}{\eta^{s}-\eta^{d}}
$$

so that the workers' valuation is ${ }^{6}$

$$
\alpha=\frac{\frac{\partial U}{\partial R} \frac{d R}{d \tau}+\frac{\partial U}{\partial p} \frac{d p}{d \tau}}{\frac{\partial U}{\partial W}} .
$$

\footnotetext{
${ }^{6} \mathrm{~A}$ similar change to a utility-based supply function to the firm gives analogous versions of equations (3) and (5), leading to the same expression for $\alpha_{f}$. Thus, while this discussion is phrased in terms of the overall market results, it is equally applicable to the firm-level expressions.
} 
- This expression indicates that the workers' valuation depends on how utility changes with the replacement rate and the layoff probability, and how the replacement rate and layoff probability change with the tax rate. ${ }^{7}$ To evaluate this expression it is useful to write $\mathrm{U}$ as a weighted average of utility when employed and unemployed, i.e. $U(W, R, p)=p u(R W, 1)+(1-p) u(W, 0)$, where $\mathrm{u}$ $(\bullet, \bullet)$ is a von Neuman-Morgenstern utility index which is a function of income and leisure, with leisure equal to 1 when not working and 0 when working. Then,

$$
\begin{aligned}
& \frac{\partial U}{\partial W}=p R u_{1}(R W, 1)+(1-p) u_{1}(W, 0), \\
& \frac{\partial U}{\partial R}=W p u_{1}(R W, 1), \text { and } \\
& \frac{\partial U}{\partial p}=u(R W, 1)-u(W, 0),
\end{aligned}
$$

where $u_{1}$ is the derivative of $u(\bullet, \bullet)$ with respect to its first argument.

Expressions (9) and (10) are clearly positive, while (11), which is the utility of a worker receiving unemployment benefits while not working minus the utility of a worker receiving the wage $\mathrm{W}$ and working, requires more discussion. For many people this expression is likely to be negative, while for others who have generous UI and jobs with regular temporary layoffs it is likely to be close to zero or positive. Evidence for a preference for temporary layoffs with UI benefits come from some union contracts with inverse seniority layoff rules (Medoff, 1979). One should also remember that a large fraction of UI benefits go to workers on temporary layoff (Katz and Meyer, 1990).

Besides the expressions in equations (9) through (11), $\frac{d R}{d \tau}$ and $\frac{d p}{d \tau}$ also determine the sign and magnitude of $\alpha$. In a cross-section, the tax rate is likely to be highly correlated with the layoff rate due to experience rating, so that $\frac{d p}{d \tau}$ will be strongly positive. However, when we examine

\footnotetext{
${ }^{7}$ Besley and Case (1994) have an independent derivation of $\alpha$ from first principles for workers' compensation.
} 
- changes in taxes below, most of the variation in taxes has little to do with contemporaneous changes in firm layoffs. Instead, it reflects current changes in state UI tax schedules or changes in layoffs at the firm level a year or more in the past. Therefore, $\frac{d p}{d \tau}$ is likely to be close to zero when the variation in $\tau$ is the change from one year to the next. For these reasons and because state schedules lead to little variation in firm replacement rates within a state, $\frac{d R}{d \tau}$ is likely to be of even less importance.

In conclusion, these observations indicate that the worker valuation of differences in tax rates will vary by type of worker and firm and depend on the source of variation in $\tau$. In a crosssection, $\alpha$ could even be negative. For the changes in tax rates that we examine and for firms with extensive UI-compensated temporary layoffs it is likely that one or both of $\frac{\partial U}{\partial p}$ and $\frac{d p}{d \tau}$ are close to zero, implying that $\alpha$ is likely to be close to zero.

The true cost of a tax to a firm as a fraction of the tax, $\beta$, is a bit easier to evaluate than $\alpha$, but there are some subtle issues. ${ }^{8}$ If a change in the tax is a permanent one because of an increase in benefit levels or layoff practices, we would expect $\beta$ to be one. However, if the increase is due to a one-time shock to a firm the true cost to the firm in reserve ratio experience rating states is just 1-e, where $\mathrm{e}$ is the marginal tax cost of a layoff. This marginal tax cost is measured as the fraction of a dollar in UI benefits which will be paid back in present value through higher future taxes. The reason that $\beta$ equals 1 -e in this case is that an increase in taxes paid affects the reserve ratio in the same way as a decrease in benefits charged. Thus, while an increase in taxes of a dollar

\footnotetext{
${ }^{8}$ While this discussion is phrased in terms of the firm, it is equally applicable to a market average.
} 
- immediately costs the firm one dollar, the firm recoups a fraction of that dollar in present value through lower taxes in the future.

A detailed derivation of e can be found in several places, including Anderson and Meyer (1994), but in it's simplest form, e can be expressed as

$$
\frac{\eta}{i+\eta}
$$

where $\eta$ is the slope of the tax schedule and $i$ is the interest rate. Empirically e averages about 0.6 in our states, but there is a great deal of variation across states and industries and across firms within a given state and industry (see Anderson and Meyer (1994) for details). A reasonable summary, then, would seem to be that permanent shifts in the level of taxes are likely associated with a $\beta$ of 1 , while firm movements along a schedule are associated with a $\beta$ of 1-e.

\section{Empirical Implementation}

The theory presented above implies that we should estimate earnings and employment equations both at the market level and at the firm level. The theory further suggests that the firmlevel regressions should include both firm-level taxes and market-level taxes as explanatory variables. Past work has estimated only market-level regressions, or individual-level earnings regressions which included only market-level tax rates. While we are able to replicate these types of specifications, we are also able to measure the actual firm tax rates. Thus, we can estimate the models implied by the theory and therefore differentiate between the effects of variation in firmlevel and market-level taxes. We construct the data sets for our analysis using administrative records from the UI systems of 8 states which participated in the Continuous Wage and Benefit History (CWBH) project. ${ }^{9}$ For each of these 8 states, quarterly wage records and weekly UI

\footnotetext{
${ }^{9}$ The eight states are the only ones available: Georgia, Idaho, Louisiana, Missouri, New Mexico, Pennsylvania, South Carolina and Washington.
} 
- receipt records were collected for a random sample of the state's covered workers from 1978 to 1984 , with the exact sample period and sampling rate differing by state.

Unfortunately, since we do not have information on hours or weeks worked in the quarter and therefore cannot calculate hourly or weekly wages, we must use quarterly earnings as our measure of the wage. Thus, it is important to only include those quarters in which a separation or accession does not occur, in order to be reasonably certain that we are comparing full quarters of work. In the Appendix we describe the identification of separations and accessions. Additionally, since it is likely that for multiple job holders at least one of those jobs is part time, we only include those with one job in a quarter. We also only include observations with quarterly earnings between $\$ 1,000$ and $\$ 50,000 .^{10}$ While such precautions should limit the number of observations which are not full quarters of full-time work, nonetheless there will be some part-time workers and those with short periods of uncompensated unemployment remaining in the data.

Each individual wage record also includes data on the firm's total quarterly payroll and average monthly employment over the quarter, allowing us to calculate average quarterly earnings at the firm as their ratio." Thus, we are able to create a firm-level data set which includes both employment and earnings from the individual wage records. All earnings measures are indexed using state average weekly earnings. We then calculate the firm's effective UI tax rate. The tax rate assigned to the firm based on a state schedule that relates a firm's tax rate to its past experience with the UI system is reported on each wage record. ${ }^{12}$ The firm does not pay this tax on the entire payroll, rather there is a tax base which varies across states and over time. In addition, there is a small federal tax of $0.7 \%$ on a base of $\$ 6,000$ prior to 1983 and $0.8 \%$ on a $\$ 7,000$ base after that. Because the taxable wage base in each state is usually much lower than average earnings, the statutory tax rate does not equal the proportion of wages paid in taxes. To appropriately account

\footnotetext{
${ }^{10}$ This is measured in 1978 dollars. Note that a worker employed for 30 hours per week at the 1978 minimum wage of $\$ 2.65$ would have quarterly earnings of $\$ 1,034$.

${ }^{11}$ The same quarterly earnings restrictions are applied to the firm data as are used with the individual-level data.

${ }^{12}$ See Anderson and Meyer $(1993,1994)$ for additional details on the UI system.
} 
- for this low tax base, we calculate a firm tax rate using the tax bill as a fraction of actual firm earnings. Appropriately measuring taxes in this way builds in a natural endogeneity, though, since the tax measure will partly depend on the earnings level. In the empirical work which follows, we estimate our model in differences and then calculate a tax measure which uses the average wage bill in the two periods. This differenced average measure is then used as an instrument and gives consistent estimates.

Having expressed the firm's tax rate as a proportion of earnings, it is now straightforward to construct a similar measure at the market level. To define a market, we have grouped similar 3digit standard industrial classifications (SIC's) into about 150 different industries. Since we are mainly concerned with labor market effects, we define the market to be local (i.e. state level), rather than national. Thus, for a local market rate, each observation is assigned the employmentweighted average tax rate over all firm observations in the state that quarter within the grouped 3digit industry. However, if there are less than 5 firm observations in the local market, all of the observations from that market are dropped. Note that for many nonmanufacturing industries, including the largest ones of services and retail trade, this labor market-based definition is probably also a reasonable definition of the output market.

Our other variable of interest is the level of employment. As was noted above, each individual wage record also contains the firm's average monthly employment over the quarter. Thus, our firm-level data set will allow us to investigate both the earnings and employment effects of the UI payroll tax. Finally, by aggregating the firm observations we also create a market-level data set, where a market is the group of 3-digit industries defined above. In this case, employment is totaled over all firms in the industry, and earnings are calculated as total industry payroll divided by total employment. Overall, then, these three data sets - the individual panel, the firm panel and the market panel - will allow us to explore this issue more fully than has previously been possible. 


\section{- REGRESSION SPECIFICATIONS}

The unique longitudinal nature of our data allows us to use panel-data techniques to address one of the major shortcomings of much of the previous work on benefits and wages. By differencing our data we can remove unmeasured characteristics of a firm's working conditions and benefits package. Additionally, when we difference the individual data we can also remove any unmeasured differences across individuals in ability or tastes. This differencing thus removes factors which many previous authors have argued severely bias empirical estimates of wage differences. We should note, however, that to the extent that these characteristics systematically change in the course of a calendar year our differencing will not completely eliminate their influence. Since our data include only a few firm-level characteristics and no individual level characteristics besides those of the employer, some part of the change in these factors would remain.

In all cases, we difference the data at annual frequencies to avoid the complications of seasonality and because tax rate and base changes generally occur once a year. Thus, for the firmlevel data we calculate annual changes within firms, while correspondingly, for the individual data, we calculate annual changes within job matches. That is, we use only individuals that remain in the same job across two years. Each of our models is estimated using data from the 3rd and 4th quarters only. Because each of our states base a firm's tax rate only on information available up through June 30 of the previous year, this restriction insures that all events which affect the tax rate will precede the time periods being differenced. Thus, for the specifications that we estimate, the variation in tax rates is due solely to changes over time within the firm. At the firm level, these changes stem from changes at the state level in the tax schedule and taxable wage base, as well as from movements of the firm along a given state tax schedule. Such movements along a tax schedule are a result of experience rating, meaning that all else equal, a firm which increases its use of the system should see an increase in its tax rate. Recall, though, that this change in tax rates is only the result of firm behavior which occurred before the quarters being differenced. At the 
- market level, the variation in tax rates is due to the same state-level changes, as well as to the aggregated effect of changes due to individual firms' movements along a given schedule.

In order to better understand the importance of each of the three sources of variation in firm-level taxes, we do the following exercise. We define alternative firm-level tax measures, each of which relies only on one of the sources of tax variation. The first measure uses only the tax schedule changes, the second uses only the tax base changes, and the third uses only the firm reserve ratio changes. Note that changes in the reserve ratio represent firm movements along the tax schedule. The sample variance of each of these measures implies that the variation due to schedule shifts is four times that due to movement along a schedule, which is itself over four times that due to changes in the tax base...

Thus, the majority of the variation in taxes stems from state changes in the tax schedule and, to a much smaller extent, the tax base. In our 8 states, 6 changed their tax schedules at least once during our sample period and all had tax base changes. Looking first at schedule changes, half of the 6 states implemented tax increases due to automatic adjustments in response to statewide declines in the UI trust fund. The other 3 states legislatively changed their schedules, with 2 mostly raising rates, and 1 mostly cutting rates. These tax schedule changes affected firms on different parts of the tax schedule in different ways and the changes interacted with different firm average wage levels to produce different effects for different firms. Turning to tax base changes, almost all of the annual changes (4 states) were due to previous legislation which indexed the base, though in real terms the base declined sharply over this period for the other states due to inflation. Those states without indexation changed their tax base in response to a $\$ 1000$ increase in the federal tax base in 1983.

Even given this understanding of the source of the tax changes, the correct lag structure in wage and employment changes that we should expect in response to the tax changes remains unclear. The annual tax changes we study have been in effect on average nine months at the time

\footnotetext{
${ }^{13}$ Note that state-specific time effects are first removed, as is described below for the main analysis. Additionally, since Pennsylvania does not use a reserve ratio system of experience rating, it is not used in this exercise.
} 
- that we examine employment and wages (the 3 rd and 4th quarter), with the tax changes known to each firm approximately a month or two before they go into effect. Additionally, some firms may have an estimate of what their tax change will be earlier based on their knowledge of their layoffs, their estimate of the weeks of UI received by their former workers, and their estimate of the state UI trust fund balance.

We use the change in the natural log of the appropriate earnings or employment measure as our dependent variable in our regressions. For the earnings equations, not only is a log specification the standard, but since the tax rates are expressed as a proportion of earnings, this specification provides us with a straightforward interpretation of the key tax coefficient in the market-level regression. The coefficient is simply the percentage of the tax which is passed on to workers in the form of lower earnings. While in the standard case the coefficient would be expected to be in the interval $[-1,0]$, where -1 implies the incidence is fully on the workers and 0 implies the incidence is fully on the firm, this restriction will not necessarily hold in this case. Depending on the relative size of $\alpha$ and $\beta$, the coefficient may be outside of the interval, as was seen in the theoretical model. Additionally, this restriction will not hold for all market structures. For example, in the case of oligopoly, the coefficient may be less than -1, as shown in Katz and Rosen (1988). There are no restrictions on the magnitude of the tax coefficient in the market employment equation, although in the standard case the employment effect would be zero if the full amount of the tax is passed on in the form of lower earnings, and negative otherwise.

In addition to the specifications implied by the theory, we also estimate some specifications which include only the firm tax rate or only the market tax rate, as these specifications are most comparable to much of the past work. Thus, we regress the change in log earnings and the change in log employment on both the change in the firm-level tax rate and the change in the market-level tax rate. We also estimate specifications in which only the change in the market-level rate is included and specifications in which only the change in the firm-level rate is included. This estimation is done with firm- and industry-level data, and also with individual-level data. 
A major advantage to our use of multiple approaches is the ability to cross-check results.

Thus, based on the theory, there is an expected relationship between earnings and employment estimates that we are able to check. More importantly, we are not restricted to only firm, industry or individual data, but rather are able to produce estimates at all 3 levels of aggregation. This provides a method for validation of our results. In particular, the results of models including only the market rate, representing the overall effect of UI on the market, should be the same across all three data sets, with one caveat. Since the models are estimated in differences, the sample of individuals remaining at the same firm across the two periods will not aggregate to the firm level. The firm level does aggregate properly to the market, however.

One final concern must be addressed before turning to the empirical results. Because our firm-level earnings measure is calculated by dividing total quarterly payroll by average monthly employment, it is greatly affected by both within-quarter employment changes and data recording errors. These factors lead to a large number of outliers in this earnings measure. Because of the outliers, for our main estimates we only include firm observations with a change in log earnings in the range $(-.5, .5)$. This restricted sample is then aggregated to obtain a corresponding marketlevel sample. Descriptive statistics for the key variables in each of the data sets used in the main analysis are presented in Table 2.

In all cases, we estimate the various specifications including state specific dummies for each quarter of data. The reason for this specification is that it is often the case in our sample that upward shifts in the state tax schedule occur after a recession, when state trust funds have been depleted. Thus, positive changes in the tax schedule will tend to be correlated with economic recovery, when employment gains are likely to be positive. In such a case, reliance on variation common to all firms due to such changes in state schedules is likely to result in employment effect estimates which are positively biased.

\section{Empirical Results}




\section{- ESTIMATES USING FIRM AND INDUSTRY DATA}

The top panel of Table 3 presents the results from several regression specifications using the annual change in average quarterly earnings and employment for the firm. ${ }^{14}$ In specification (1) both the change in the market-level tax rate and in the firm-level tax rate are included, while in specifications (2) and (3) only the change in either the market-level or the firm-level rate respectively is included. The models are estimated using a 3-stage procedure as follows. First, 2SLS estimates are obtained, where the change in the taxbill as a fraction of average earnings over the two periods is used as an instrument. ${ }^{15}$ The squared residuals from this model are then used as the dependent variable in a regression on a constant and the inverse of average employment at the firm over the two periods. The inverse of the predicted values from this regression are then used as weights in the final IV estimation procedure. ${ }^{16}$

The pattern of the results in this panel of Table 3 is generally in accordance with the theory. Looking first at model (1), the coefficients on both the market and firm tax are negative and significantly different from zero in the top half of the panel. In the bottom half of the panel, the employment effects are as expected, given the earnings effects, with significantly positive and negative coefficients on the market and firm tax respectively. Note that this result is related to the work of Baker and Breshnahan (1988), who use firm level cost shifters as instruments for a firm's quantity and see if it affects other firms' prices. Here, we examine if changes in other firms' input prices affect a given firm's use of inputs. Our result also supports the prediction found in the oligopoly literature that a factor which raises a firm's rivals' costs should decrease their output and increase the firm's output (See Dixit, 1986 or Shapiro, 1989). Since an increase (decrease) in

\footnotetext{
${ }^{14}$ Note that the standard errors in our tables are understated since we do not account for the correlation between adjacent changes in wages and employment.

${ }^{15}$ Note that as would be expected, OLS estimates of earnings (employment) equations are severely negatively (positively) biased by the natural endogeneity of the tax measure.

${ }^{16}$ We also estimated models in which the number of firms in the industry was used as the basis for forming the weights, but employment was a better predictor of the squared residuals.
} 
- output would be expected to increase (decrease) the use of labor, our employment result confirms this prediction.

Model (2) provides an estimate of the overall market effect of the UI tax, and is similar to the specifications used in much of the past work. The results here are also similar, indicating that there is no employment effect, only a wage effect. While the point estimates actually imply a positive employment effect of 0.298 and that only about 70 percent of the tax is shifted, the standard errors are such that we cannot reject that the coefficients on earnings and employment are -1 and 0 respectively. Recall, also, that the theory implies that a zero employment effect could be obtained with a less than complete drop in earnings, and that the effect could even be positive. The results from model (3) indicate that the firm-level tax effects are very different from the marketlevel tax effects of model (2), implying that only about one quarter of the firm-level tax is passed on. Correspondingly, there is a significantly negative effect on firm-level employment. This finding that firms are unable to pass on a substantial fraction of the difference in firm-level taxes is an important one, since it confirms what has only been assumed in past work on experience rating effects.

The overall effect of the market tax on firm employment estimated in model (2) should aggregate to a market-level effect. The middle panel of Table 3 presents estimates using the market-level data set. A similar 3-stage procedure is followed, although in this case the number of firms in the market is used as the basis for forming the weights. ${ }^{17}$ The estimated earnings effect is very similar to that from the corresponding specification (model (2) in the top panel) using firm data, at -0.81 versus -0.72 . While the point estimate of the employment effect is quite a bit larger, it is still not significantly different from zero. Thus, both the firm-level and market-level data provide evidence which is in accordance with past findings of no employment losses. The marketlevel analyses, however, mask the reallocation of employment across firms which is taking place at the firm level and which was seen in the top panel. By explicitly accounting for the variation

\footnotetext{
${ }^{17}$ We also estimated models in which employment in the industry was used as the basis for forming the weights, but number of firms was a beter predictor of the squared residuals.
} 
- within markets in firm tax rates, we are able to capture this substantial effect, which has previously been ignored.

While it is clear that these results are generally consistent with the basic predictions of the theory, we can push the theory further to determine the implied values of $\alpha, \beta$ and the demand and supply elasticities. Focusing on equations (1), (3) and (5), it is clear that we must make some assumptions, since there are more parameters than equations. Thus, we first assume that $\alpha_{\mathrm{m}}=\alpha_{\mathrm{f}}=$ $\alpha$. Now given equation (3), model (1) of the top panel implies that $\alpha=0.194$. Substituting this into equation (5), we can solve for $\beta_{\mathrm{m}}$ in terms of the ratio of the elasticities of supply and demand. Alternatively, we can substitute into equation (1) and use model (2), but subject to rounding error, the resulting equation is the same. Thus, we can only discuss the implications in terms of this relationship between $\beta_{m}$ and the ratio of the elasticities of supply and demand.

Based on the theory, then, Table 3 implies that, on average, worker valuation of UI benefits is significantly below 1 , at just 0.194 . Given that the marginal tax cost, e, averages 0.6 in our data, $\beta$ is expected to be between 0.4 and 1 . However, since schedule shifts dominate, it is likely to be closer to 1 . For the case of $\beta=1$, our results imply that the ratio of the elasticity of supply to the elasticity of demand is -0.55 , where this ratio is negatively related to $\beta$. For each 0.1 decline in $\beta$, the ratio increases by about 0.19 . According to Hamermesh and Reese (1993), a midrange estimate for the long run elasticity of demand is -1.0 , implying that the labor supply elasticity is 0.55. While this is consistent with their reports of midrange labor supply estimates of 0 for men and 0.80 for women, it is likely to be an underestimate of the market elasticity. The ability of workers to move between industries implies that labor supply for the market should be more elastic. Similarly, labor demand may be less elastic over one year, than in the long run, again implying that our ratio is underestimated. 


\section{ESTIMATES USING INDIVIDUAL DATA}

The second main approach followed in the past has been to use data on individuals. Thus, we also use individual-level data to estimate the effect of the UI tax on individual quarterly earnings. As seen in the bottom panel of Table 3, the results are very different from both the past literature and the results of the top panels of Table 3 . In this case, we estimate a large positive effect of the market rate, and the effect of the firm rate is only negative when controlling for the market rate. Interestingly, though, this negative effect in model (1) is very similar in size to that of model (1) in the top panel of Table 3. Thus, it is mainly the effect of the market tax which differs across the samples. The source of this instability is unclear, although we should note that the individual sample does not aggregate to the firm sample. Because only individuals remaining at the same firm across the two years are included in the individual sample, more unstable workers and new workers at the firm are not included.

A possible source of positive bias in estimates of earnings effects is the existence of compensating differentials, given our reliance on firms' movement along state tax schedules as well as the differential impact of state tax schedule changes. Recall that movements along a given schedule are due to firm behavior, since the UI system is experience rated. A job providing a higher risk of unemployment may require a positive compensating wage differential. ${ }^{18}$ If the change in layoff behavior which led to the change in the tax rate is permanent, then there has been a change in the risk of layoff, and there should be a resultant change in compensation. In such a case, our estimated coefficient for the effect of the UI tax on earnings would be positively biased. Recall, though, that a firm's tax rate is only adjusted to its layoff behavior with a lag. Thus, if compensation is adjusted contemporaneously, our estimates should be unaffected. Additionally, if

\footnotetext{
${ }^{18}$ See Abowd and Ashenfelter (1981), Bronars (1983) and Topel (1984) for tests of compensating differentials for unemployment. We should note that these authors do not account for the effects of differences in unemployment insurance taxes between high and low layoff firms.
} 
- the change is only temporary, there should be no change in compensation policy. Also unclear is why any such bias would differ significantly across the individual- and firm-level samples.

\section{ALTERNATIVE ESTIMATES}

While we think the estimates presented above are preferable on a priori grounds, we tried several alternatives. Tables 4 and 5 present two of these. The effect of outliers is clearly seen in 
- Table 4, which uses the unrestricted data. ${ }^{19}$ In most specifications, the estimated coefficients are larger in absolute value than those from Table 3, and in all cases the standard errors have increased. Additionally, results appear somewhat less consistent with the theory across specifications, although the large standard errors make conclusions difficult to draw. Thus, while the point estimates of positive employment effects are larger in Table 4 than in Table 3, the effects remain statistically insignificantly different from zero in each case.

Table 5 presents estimates using all 4 quarters of data. Recall that our preferred estimates are restricted to observations from the $3 \mathrm{rd}$ and 4 th quarters out of concern for possible biases. To examine the potential biases consider that we estimate differenced equations of the following sort:

$$
E_{y, q}-E_{y-1, q}=\gamma\left(\tau_{y}-\tau_{y-1}\right)+\left(\varepsilon_{y, q}-\varepsilon_{y-1, q}\right),
$$

where $\mathrm{E}_{\mathrm{y}, \mathrm{q}}$ is earnings or employment in year $\mathrm{y}$ and quarter $\mathrm{q}$. Information dated at time $(\mathrm{y}-1,2)$ and before will influence $\tau_{y}$, implying that if $E$ affects $\tau$, then $\tau_{y}$ will be correlated with $\varepsilon_{y-1, q}$ for $\mathrm{q}=1$ or $\mathrm{q}=2$. Note that since $\tau_{\mathrm{y}}$ enters (13) positively and $\varepsilon_{\mathrm{y}-1, \mathrm{q}}$ enters negatively, $\gamma$ will be biased in the opposite direction of any correlation between $E$ and $\tau$.

Looking at Table 5, there appears to be very little such effect for firm earnings, since point estimates in the top half of the top panel are only slightly less negative than those in Table 3 . Estimates of the impact of taxes on employment are very different, however, being much more negative here than in Table 3. While this result is consistent with the tax rate being a positive function of past employment, there are no strong theoretical predictions of such a correlation. The findings are similar at the market level, though, in that the estimated earnings effects are much like those of Table 3, while the employment effects are much more negative. By contrast, the individual earnings results are very different here from those of Table 3. As was the case with firm-level and market-level employment, individual earnings are much more negative in this case. Overall, then, while these alternative estimates are in some instances supportive of those from our

\footnotetext{
${ }^{19}$ Recall that the $\ln ($ earnings) restriction applies to firm average earnings, so there are no alternative individual-level
} 
- preferred specifications, there are some large differences, the exact sources of which remain a puzzle.

\section{Conclusions}

In this paper we theoretically and empirically examine the common, but previously unexamined, case of a firm-varying tax which is used to finance a fringe benefit. While we use data from the experience-rated unemployment insurance (UI) system, it is important to realize that differential treatment of firms (such as special considerations for small business) under mandated benefits laws lead to costs which vary across firms and are analogous to experience-rated taxes. We present a theoretical model which highlights the importance of considering this variation in taxes or costs both within and across markets.

Despite the importance of this firm-level variation in taxes and costs, past work on incidence has only explored market-level effects. Our administrative data from state UI systems provides information on firm-level taxes, along with employment and individual and firm average earnings, which allows us to fill this gap. Another major advantage to our approach is that we use longitudinal data which is differenced within firms or within individual-firm matches. A common problem in past work on incidence and compensating differentials is that of unmeasured firm and worker characteristics that may be correlated with wages, fringe benefits and working conditions. By examining only annual changes in either firm average earnings and employment or in individual worker earnings at the same firm, we remove all unmeasured characteristics which do not change in the course of a year.

Our results suggest that most of the market level tax is born by the worker. However, this does not imply that there are no employment effects of the tax. Rather, we find that individual firms can only pass on a small share of the within market differences in the tax they face, leading to substantial employment reallocation across firms. This last finding is especially significant as it

estimates. 
- confirms what has previously only been assumed by the UI literature on the effects of experience rating. Additionally, we find that firm and market level taxes have opposite effects on employment. This result has been predicted by theory in the industrial organization literature, but not previously tested. While our ability to examine both within and across market variation is a significant step forward, our market-level results remain supportive of previous market-level findings. 


\section{- Appendix on Identification of Turnover}

In order to identify separations and accessions, we use the person and firm identifier available on the wage records to create job-match histories for each individual. If a specific job match last appears in a quarter other than the final quarter of data collection, we identify a separation to have occurred at that time. Similarly, if a specific job match first appears in a quarter other than the first quarter of data collection, we identify an accession to have occurred at that time. A drawback to this method is that separations which are followed by a return to the same job without a full calendar quarter intervening will be missed. However, by matching UI claims records to the wage records we can identify those short temporary separations that result in UI receipt. We then are able to drop any quarterly record for which we have coded an accession or separation or any weeks of UI receipt. Additionally, we drop the first and last quarters of data collection, since we cannot tell whether or not an accession or separation occurs in those quarters. 


\section{- References}

Aaron, Henry J. and Bosworth, Barry P., 1994. "Economic Issues in Reform of Health Care Financing," Brookings Papers on Economic Activity: Microeconomics 1994, 249-299.

Abowd, John and Orley Ashenfelter (1981): "Unanticipated Unemployment, Temporary Layoffs, and Compensating Wage Differentials," in Studies in Labor Markets, ed. by Sherwin Rosen. Chicago: University of Chicago Press for NBER.

Anderson, Patricia M. and Bruce D. Meyer (1992): "The Incentives and Cross Subsidies of the UI Payroll Tax," unpublished manuscript.

Anderson, Patricia M. and Bruce D. Meyer (1993): "Unemployment Insurance in the United States: Layoff Incentives and Cross-Subsidies," Journal of Labor Economics 11, S70-S95.

Anderson, Patricia M. and Bruce D. Meyer (1994): "The Effect of Unemployment Insurance Taxes and Benefits on Layoffs Using Firm and Individual Data," NBER Working Paper No. 4960.

Baker, Jonathan B. and Timothy F. Bresnahan (1988): "Estimating the Residual Demand Curve Facing a Single Firm." International Journal of Industrial Organization, 6, 283-300.

Besley, Timothy and Anne Case (1994): "Unnatural Experiments? Estimating the Incidence of Endogenous Policies," NBER Working Paper No. 4956.

Brechling, Frank. "The Incentive Effects of the U.S. Unemployment Insurance Tax." In Research in Labor Economics, 1, edited by Ronald Ehrenberg. Greenwich, Connecticut: JAI Press, 1977. (a)

Brechling, Frank. "Unemployment Insurance Taxes and Labor Turnover: Summary of Theoretical Findings." Industrial and Labor Relations Review 30 (July 1977): 483-494. (b)

Brechling, Frank (1981): "Layoffs and Unemployment Insurance," in Studies in Labor Markets, edited by Sherwin Rosen. Chicago: The University of Chicago Press, 187-202.

Bronars, Stephen (1983): "Compensating Wage Differentials and Layoff Risk in U.S. Manufacturing Industries," Ph.D. Dissertation, University of Chicago.

Brown, Charles (1980): "Equalizing Differences in the Labor Market,". Quarterly Journal of Economics, 94 113-134.

Burkhauser, Richard B., and John A. Turner. 1985. "Is the Social Security Payroll Tax a Tax?" Public Finance Quarterly 13 (July), 253-267.

Card, David and Phillip B. Levine. "Unemployment Insurance Taxes and the Cyclical and Seasonal Properties of Unemployment," Journal of Public Economics 53 (1994), pp. 1-29.

Dixit, Avinash (1986): "Comparative Statics for Oligopoly," International Economic Review, 27, February 1986, pp. 107-122. 
- Gruber, Jonathan. "The Incidence of Mandate Maternity Benefits" American Economic Review, June 1994, 84 (3), pp. 622-641.

Gruber, Jonathan, and Alan Krueger, 1991, "The Incidence of Mandate Employer- Provided Insurance: Lessons from Workers' Compensation Insurance," in Tax Policy and the Economy, Edited by David Bradford, 111-143. Cambridge, Mass.: National Bureau of Economic Research.

Hamermesh, Daniel S. Jobless Pay and the Economy. Baltimore: The Johns Hopkins University Press, 1977.

Hamermesh, Daniel S. (1993): "Labor Demand," Princeton, NJ: Princeton University Press.

Hamermesh, Daniel S. and Albert Rees (1993): The Economics of Work and Pay. New York: HarperCollins.

Katz, H.L. and H.S. Rosen (1988?) "Tax Analysis in an Oligopoly Model," Public Finance Quarterly.

Katz, Lawence F., and Bruce D. Meyer (1990): "Unemployment Insurance, Recall Expectations, and Unemployment Outcomes," Quarterly Journal of Economics, November 1990, 105, pp. 973-1002.

Leibowitz, Arleen (1983): "Fringe Benefits in Employee Compensation," in The Measurement of Labor Cost, ed. by Jack E. Triplett, Chicago: University of Chicago Press.

Lester, Richard A., The Economics of Unemployment Compensation, Industrial Relations Section, Princeton University, 1962.

Medoff, James L. "Layoffs and Alternatives under Trade Unions in U.S. Manufacturing," American Economic Review 69 (June 1979): 380-395.

Montgomery, Edward, Kathryn Shaw, and Mary Ellen Benedict (1992): "Pensions and Wages: An Hedonic Price Theory Approach," International Economic Review, 33, 111-128.

Rosen, Sherwin (1987): "The Theory of Equalizing Differences," in The Handbook of Labor Economics, ed. by Orley Ashenfelter and Richard Layard,Amsterdam: North Holland.

Shapiro, Carl (1989): "Theories of Oligopoly Behavior," in Handbook of Industrial Organization, edited by R. Schmalensee and R.D. Willig. Amsterdam: Elsevier.

Smith, Robert S. and Ronald G. Ehrenberg (1983): "Estimating Wage-Fringe Trade-Offs: Some Data Problems," in The Measurement of Labor Cost, ed. by Jack E. Triplett, Chicago: University of Chicago Press.

Summers, Lawrence H. 1989. "Some Simple Economics of Mandate Benefits." American Economic Review, Papers and Proceedings 79 (May): 177-183.

Topel, Robert H. "On Layoffs and Unemployment Insurance," American Economic Review 73 (September 1983): 541-559. 
- Topel, Robert H. "Experience Rating of Unemployment Insurance and the Incidence of Unemployment." Journal of Law \& Economics 27 (April 1984): 61-90.

Topel, Robert H. (1984): "Equilibrium Earnings, Turnover, and Unemployment: New Evidence," Journal of Labor Economics, 2, 500-522.

Topel, Robert H. "Financing Unemployment Insurance: History, Incentives, and Reform." In Unemployment Insurance, edited by W. Lee Hansen and James F. Byers. Madison, Wisconsin: University of Wisconsin Press, 1990.

Triplett, Jack E. (1983): "An Essay on Labor Cost," in The Measurement of Labor Cost, ed. by Jack E. Triplett, Chicago: University of Chicago Press.

Woodbury, Stephen A. and Wei-Jang Huang (1991): The Tax Treatment of Fringe Benefits, Kalamzoo, MI: W.E. Upjohn Institute. 
Table 1

Predicted Signs of Regression Coefficients

\begin{tabular}{|c|c|c|c|c|}
\hline & \multicolumn{2}{|c|}{ Earnings Equations } & \multicolumn{2}{|c|}{ Employment Equation } \\
\hline $\begin{array}{l}\text { firm-level } \\
\text { regression }\end{array}$ & $\begin{array}{l}\text { Coefficient on } \\
\text { market tax }\end{array}$ & $\begin{array}{l}\text { Coefficient on } \\
\text { firm tax }\end{array}$ & $\begin{array}{l}\text { Coefficient on } \\
\text { market tax }\end{array}$ & $\begin{array}{l}\text { Coefficient on } \\
\text { firm tax }\end{array}$ \\
\hline$\alpha=0, \beta=1$ & negative & zero & positive & negative \\
\hline $0<\alpha<\beta$ & less negative & $\begin{array}{c}\text { becomes } \\
\text { negative }(=-\alpha)\end{array}$ & less positive & less negative \\
\hline$\alpha=\beta$ & zero & negative $(=-\alpha)$ & zero & zero \\
\hline$\alpha>\beta$ & positive & negative $(=-\alpha)$ & negative & positive \\
\hline $\begin{array}{c}\text { market-level } \\
\text { regression }\end{array}$ & $\begin{array}{c}\text { Coefficient on } \\
\text { market tax }\end{array}$ & & $\begin{array}{c}\text { Coefficient on } \\
\text { market tax }\end{array}$ & \\
\hline$\alpha=0, \beta=1$ & negative & & negative & \\
\hline $0<\alpha<\beta$ & more negative & & less negative & \\
\hline$\alpha=\beta$ & $\begin{array}{l}\text { even more } \\
\text { negative }\end{array}$ & & zero & \\
\hline$\alpha>\beta$ & negative & & positive & \\
\hline
\end{tabular}

Notes: $\alpha$ and $\beta$ refer to $\alpha_{m}$ and $\beta_{m}$ and $\alpha_{\mathrm{l}}$ and $\beta_{\mathrm{f}}$ for coefficient on market tax and firm tax, respectively. See text for details. 
Table 2

Descriptive Statistics for Key Variables

\begin{tabular}{|c|c|c|c|c|c|}
\hline & Mean & $\begin{array}{c}\text { Standard } \\
\text { Deviation }\end{array}$ & Minimum & Maximum & $\begin{array}{c}\text { Number of } \\
\text { Obs }\end{array}$ \\
\hline \multicolumn{6}{|l|}{ Individual-Level Data } \\
\hline$\Delta$ Firm-Level Tax Rate & -0.0004 & 0.004 & -0.057 & 0.052 & 1422877 \\
\hline$\Delta$ Market-Level Tax Rate & -0.0002 & 0.003 & -0.018 & 0.022 & 1422877 \\
\hline$\Delta$ Ln(Earnings) & 0.016 & 0.215 & -3.539 & 3.347 & 1422877 \\
\hline \multicolumn{6}{|l|}{ Firm-Level Data } \\
\hline$\Delta$ Firm-Level Tax Rate & -0.0004 & 0.005 & -0.046 & 0.050 & 410709 \\
\hline$\Delta$ Market-Level Tax Rate & -0.0003 & 0.003 & -0.020 & 0.022 & 410709 \\
\hline$\Delta \operatorname{Ln}$ (Earnings) & -0.011 & 0.169 & -0.500 & 0.500 & 410709 \\
\hline$\Delta \operatorname{Ln}($ Employment $)$ & 0.004 & 0.287 & -7.716 & 8.296 & 410709 \\
\hline \multicolumn{6}{|l|}{ Industry-Level Data } \\
\hline$\Delta$ Market-Level Tax Rate & -0.0003 & 0.004 & -0.020 & 0.022 & 7114 \\
\hline$\Delta \mathrm{Ln}$ (Earnings) & -0.005 & 0.059 & -0.460 & 0.390 & 7114 \\
\hline$\Delta \mathrm{Ln}$ (Employment) & 0.003 & 0.107 & -1.830 & 2.376 & 7114 \\
\hline
\end{tabular}

Notes: Changes are annual changes calculated using quarterly data (i.e 1983:3 - 1982:3, 1983:4 $1982: 4$, etc.). For individual-level data, only workers remaining at the same firm in both quarters are used. See text for details. 
Table 3

Weighted IV Estimates of the

Effect of UI Taxes on

Firm and Industry Average Earnings and Employment and on Individual Earnings

\begin{tabular}{|c|c|c|c|c|}
\hline Dependent Variable & $\begin{array}{c}\Delta \text { Market-Level } \\
\text { Tax Rate }\end{array}$ & $\begin{array}{c}\Delta \text { Firm-Level } \\
\text { Tax Rate }\end{array}$ & $\begin{array}{c}\text { Number of } \\
\text { Obs }\end{array}$ & $\mathrm{R}^{2}$ \\
\hline \multicolumn{5}{|l|}{ Firm Data } \\
\hline \multirow{2}{*}{ (1) $\Delta \operatorname{Ln}$ (Earnings) } & -0.520 & -0.194 & 410709 & 0.007 \\
\hline & $(0.231)$ & $(0.081)$ & & \\
\hline \multirow[t]{2}{*}{ (2) $\Delta \operatorname{Ln}($ Earnings) } & -0.715 & -- & 410709 & 0.007 \\
\hline & $(0.217)$ & & & \\
\hline \multirow[t]{2}{*}{ (3) $\Delta \operatorname{Ln}($ Earnings) } & -- & -0.260 & 410709 & 0.007 \\
\hline & & $(0.076)$ & & \\
\hline \multirow[t]{2}{*}{ (1) $\Delta \operatorname{Ln}($ Employment $)$} & $-\overline{1} .15 \overline{8}$ & -0.862 & $\overline{4} \overline{10} \overline{70} \overline{9}$ & $\overline{0} . \overline{0} \overline{1} \overline{1}$ \\
\hline & $(0.403)$ & $(0.139)$ & & \\
\hline \multirow{2}{*}{ (2) $\Delta \operatorname{Ln}($ Employment $)$} & 0.298 & -- & 410709 & 0.011 \\
\hline & $(0.377)$ & & & \\
\hline \multirow[t]{2}{*}{ (3) $\Delta \operatorname{Ln}($ Employment $)$} & - & -0.724 & 410709 & 0.011 \\
\hline & & $(0.130)$ & & \\
\hline \multicolumn{5}{|l|}{ Industry Data } \\
\hline \multirow[t]{2}{*}{ (1) $\Delta \operatorname{Ln}$ (Earnings) } & -0.810 & N/A & 7114 & 0.076 \\
\hline & $(0.392)$ & & & \\
\hline \multirow[t]{2}{*}{ (1) $\Delta \operatorname{Ln}($ Employment $)$} & $\overline{0} . \overline{9} \overline{1} \overline{2}-$ & $\overline{\mathrm{N}} / \overline{\mathrm{A}}$ & $-\overline{7114}$ & $\overline{0} \overline{1} \overline{29}$ \\
\hline & $(0.681)$ & & & \\
\hline \multicolumn{5}{|l|}{ Individual Data } \\
\hline \multirow[t]{2}{*}{ (1) $\Delta \operatorname{Ln}($ Earnings $)$} & 1.102 & -0.177 & 1422877 & 0.005 \\
\hline & $(0.165)$ & $(0.092)$ & ' & \\
\hline \multirow[t]{2}{*}{ (2) $\Delta \mathrm{Ln}($ Earnings $)$} & 0.928 & -- & 1422877 & 0.005 \\
\hline & $(0.137)$ & & & \\
\hline \multirow[t]{2}{*}{ (3) $\Delta \operatorname{Ln}($ Earnings) } & -- & 0.120 & 1422877 & 0.005 \\
\hline & & $(0.077)$ & & \\
\hline
\end{tabular}

Notes: See notes to Table 2. The change in the tax bill as a fraction of averge earnings across the two years is used as an instrument. Weights are formed based on firm employment for the firm data and based on number of firms in the market for the industry data. The individual data are not weighted. All models also include separate state dummies for each quarter of data. See text for details. 
Table 4

Weighted IV Estimates of the Effect of UI Taxes on

Firm and Industry Average Earnings and Employment

Unrestricted Sample

\begin{tabular}{|c|c|c|c|c|}
\hline Dependent Variable & $\begin{array}{c}\Delta \text { Market-Level } \\
\text { Tax Rate }\end{array}$ & $\begin{array}{c}\Delta \text { Firm-Level } \\
\text { Tax Rate }\end{array}$ & $\begin{array}{c}\text { Number of } \\
\text { Obs }\end{array}$ & $\mathrm{R}^{2}$ \\
\hline \multicolumn{5}{|l|}{ Firm Data } \\
\hline \multirow[t]{2}{*}{ (1) $\Delta \operatorname{Ln}($ Earnings $)$} & -1.527 & 0.147 & 440402 & 0.092 \\
\hline & $(0.387)$ & $(0136)$ & & \\
\hline \multirow{2}{*}{ (2) $\Delta$ Ln(Earnings) } & -1.379 & -- & 440402 & 0.092 \\
\hline & $(0.360)$ & & & \\
\hline \multirow[t]{2}{*}{ (3) $\Delta$ Ln(Earnings) } & -- & -0.045 & 440402 & 0.092 \\
\hline & & $(0.127)$ & & \\
\hline \multirow[t]{2}{*}{ (1) $\Delta$ Ln(Employment) } & $-\overline{1} . \overline{9} \overline{4} \overline{1}$ & $-1 . \overline{196}$ & $\overline{4} \overline{4} \overline{4} \overline{0} \overline{2}^{-}$ & $\overline{0} \overline{0} \overline{7} \overline{4}$ \\
\hline & $(0.494)$ & $(0.170)$ & & \\
\hline \multirow[t]{2}{*}{ (2) $\Delta \mathrm{Ln}($ Employment) } & 0.742 & -- & 440402 & 0.074 \\
\hline & $(0.461)$ & & & \\
\hline \multirow[t]{2}{*}{ (3) $\Delta \operatorname{Ln}($ Employment) } & -- & -0.969 & 440402 & 0.074 \\
\hline & & $(0.160)$ & & \\
\hline \multicolumn{5}{|l|}{ Industry Data } \\
\hline \multirow[t]{2}{*}{ (1) $\Delta$ Ln(Earnings) } & -0.387 & N/A & 7184 & 0.270 \\
\hline & $(0.751)$ & & & \\
\hline (1) $\Delta \operatorname{Ln}($ Employment) & $\begin{array}{l}-\overline{0.9 \overline{9}} \overline{6} \\
(0.809)\end{array}$ & $-\bar{N} / A^{-}$ & $-\overline{7184^{--}}$ & $\overline{0} \overline{3} \overline{4} \overline{1}$ \\
\hline
\end{tabular}

Notes: See notes to Table 3. See text for details. 
Table 5

Weighted IV Estimates of the Effect of UI Taxes on

Firm and Industry Average Earnings and Employment and on Individual Earnings

All Quarters Sample

\begin{tabular}{|c|c|c|c|c|}
\hline Dependent Variable & $\begin{array}{c}\Delta \text { Market-Level } \\
\text { Tax Rate }\end{array}$ & $\begin{array}{l}\Delta \text { Firm-Level } \\
\text { Tax Rate }\end{array}$ & $\begin{array}{c}\text { Number of } \\
\text { Obs }\end{array}$ & $\mathbf{R}^{2}$ \\
\hline (1) $\Delta \operatorname{Ln}$ (Earnings) & $\begin{array}{l}-0.411 \\
(0.162)\end{array}$ & $\begin{array}{l}-0.118 \\
(0.054)\end{array}$ & 810574 & 0.009 \\
\hline (2) $\Delta \operatorname{Ln}($ Earnings) & $\begin{array}{l}-0.529 \\
(0.153)\end{array}$ & -- & 810574 & 0.009 \\
\hline (3) $\Delta \operatorname{Ln}$ (Earnings) & -- & $\begin{array}{r}-0.165 \\
(0.051) \\
\end{array}$ & 810574 & 0.009 \\
\hline (1) $\Delta \operatorname{Ln}($ Employment) & $\begin{array}{l}0.551 \\
(0.287)\end{array}$ & $\begin{array}{l}-1.444 \\
(0.094)\end{array}$ & 810574 & 0.008 \\
\hline (2) $\Delta \operatorname{Ln}($ Employment $)$ & $\begin{array}{l}-0.883 \\
(0.271)\end{array}$ & -- & 810574 & 0.008 \\
\hline Industry Data & -- & $\begin{array}{l}-1.385 \\
(0.089)\end{array}$ & 810574 & 0.008 \\
\hline (1) $\Delta \operatorname{Ln}$ (Earnings) & $\begin{array}{c}-0.855 \\
(0.272)\end{array}$ & N/A & 13828 & 0.088 \\
\hline (2) $\Delta \operatorname{Ln}($ Employment) & $\begin{array}{l}-1.184 \\
(0.489) \\
\end{array}$ & $\bar{N} / \bar{A}^{--n}$ & $1 \overline{3} \overline{8} 28^{-}$ & $\overline{0} . \overline{0} \overline{9} 0$ \\
\hline (1) $\Delta \operatorname{Ln}($ Earnings) & $\begin{array}{c}0.221 \\
(0.121)\end{array}$ & $\begin{array}{l}-0.202 \\
(0.062)\end{array}$ & 2782397 & 0.009 \\
\hline (2) $\Delta \operatorname{Ln}$ (Earnings) & $\begin{array}{r}0.024 \\
(0.104)\end{array}$ & -- & 2782397 & 0.009 \\
\hline (3) $\Delta \operatorname{Ln}($ Earnings $)$ & -- & $\begin{array}{l}-0.153 \\
(0.054)\end{array}$ & 2782397 & 0.009 \\
\hline
\end{tabular}

Notes: See notes to Table 3. See text for details. 